УДК 81'25

DOI https://doi.org/10.26661/2414-1135-2021-82-8

\title{
НЕОЛОГІЗМИ ТА ЇХНЯ ЕКСПЛІКАЦІЯ В АНГЛІЙСЬКОМУ МОВЛЕННІ
}

\author{
Гурко О. В. \\ доктор філологічних наук, дочент, \\ завідувач кафедри англійської мови для нефілологічних спеціальностей \\ Дніпровський начіональний університет імені Олеся Гончара \\ пр. Гагаріна, 72, Дніпро, Україна \\ orcid.org/0000-0002-2839-2400 \\ hurko.o.v@gmail.com
}

Ключові слова: нова розмовна лексика, найменування, сфери використання, аналітичний та інтерактивний етап, найчастотніші групи новотворів, носії англійської мови.
Поява неологізмів зумовлена стрімкою активізацією суспільства та виникненням нових реалій, які потребують вербалізації в мові. Утворення нових лексем відбувається здебільшого 3 власного матеріалу через словотвірні моделі та на основі переосмислення наявних одиниць. У межах наукової розвідки неологізми трактуємо як лексеми, що виникли в англійській мові протягом останніх двох десятиліть та виокремлюємо п'ять теоретичних підходів до їх вивчення (стилістичний, денотативний, структурний, етимологічний $\mathrm{i}$ словниковий). У статті семантично диференціюємо групи англійських неологізмів, що вербалізують сферу розмовної лексики XXI ст., окреслюємо причини виникнення неологізмів та виявляємо найпродуктивніші царини вживання новітніх одиниць. Об'єктом вивчення є новітня розмовна лексика англійської мови XXI ст., а предметом наукового аналізу - семантична структура неологізмів початку XXI ст. Матеріалом дослідження слугували неологізми, вибрані 3 англо-українського словника нової розмовної лексики та фразеології за редакцією Ю.А. Зацного та А.В. Янкова та Oxford Online Dictionary. Основними сферами функціонування нових розмовних одиниць є комп'ютерні технології, громадське життя, генна інженерія, антропоцентрична, суспільно-політична та соціально-економічна. До домінувальних інноваційних одиниць уналежнено однослівні мовні лексеми, які здебільшого виражені іменниками, що свідчить про потребу носіїв мови називати явища або ситуації. Механізми продукування нових слів мають специфічну природу і їх використовують мовці як стратегії переборювання комунікативних труднощів. Задля економії власного часу користувачі Інтернет-простору вигадують чимало новотворів, що швидко підхоплюють і поширюють мовці та блогери. Неологізація стає дедалі більш поширеною, оскільки це зручний метод передавання інформації. Інтерактивний етап дослідження неологізмів засвідчив слабку кононативну обізнаність респондентів у представлених одиницях, проте, спираючись на контекст, інформанти з'ясували значення 90\% наведених слів. Перспективу нових студій вбачаємо в компаративному вивченні новотворів різних мов. 


\title{
NEOLOGISMS AND THEIR EXPLICATION IN ENGLISH SPEECH
}

\author{
Hurko O. V. \\ Doctor of Philological Sciences, Associate Professor, \\ Head of the Department of English Language for Non-Philological Specialities \\ Oles Honchar Dnipro National University, \\ Gagarin avenue, 72, Dnipro, Ukraine \\ orcid.org/0000-0002-2839-2400 \\ hurko.o.v@gmail.com
}

Key words: new colloquial vocabulary, names, spheres of usage, analytical and interactive stage, the most frequent groups of new words, native speakers of English.
The emergence of neologisms is due to the rapid activation of society and the occurrence of new realities that require verbalization in language. The formation of new lexemes is mostly from their own material through wordforming models and on the basis of rethinking existing units. Within scientific research, we interpret neologisms as lexemes that have emerged in English over the past two decades and identify five theoretical approaches to their study. We semantically differentiate groups of English neologisms that verbalize the sphere of colloquial vocabulary of the XXI century, outline the causes of neologisms and identify the most productive areas of usage of the latest units. The object of study is the modern colloquial vocabulary of the English language of the XXI century, and the subject of scientific analysis - the semantic structure of neologisms. The material of the research was neologisms selected from the English-Ukrainian dictionary of new colloquial vocabulary and phraseology and Oxford Online Dictionary. The main areas of functioning of the new conversational units are computer technology, public life, genetic engineering, anthropocentric, socio-political and socio-economic. Dominant neologisms include single-word language lexemes, which are mostly expressed by nouns, which indicates the need for native speakers to name phenomena or situations. Mechanisms for producing new words have a specific nature and are used by speakers as strategies for overcoming communication difficulties. To save their own time, Internet users invent a lot of new words that are quickly distributed by speakers and bloggers. The interactive stage of the study of neologisms showed a weak connotative awareness of the respondents in the presented units, but based on the context, the informants found out the meaning of $90 \%$ of the words. The prospect of further research can be seen in the comparative investigation of innovations of different languages.
Постановка проблеми. Чимало нових розмовних слів проходять процес соціалізації, а й подекуди лексикалізації, проте не завжди посідають істотне місце в мовленні. Спираючись на студіювання вітчизняних й зарубіжних дослідників (О.В. Гурко [2], С.О. Снікеєва [3], К.Ф. Заболотний [4], Ю.А. Зацний та А.В. Янков [5; 6], О.В. Ткачик [7], L. Min-Chang [9] та ін.), зауважимо, що в будьякій мові функціонують лексеми, які мають нове конотативне забарвлення. Саме тому питання про належність тих чи тих розмовних одиниць до неологізмів є нині суперечливим, оскільки думки науковців неоднозначні щодо встановлення проміжку, до якого слово все ще залишається неологізмом. Зокрема, T.I. Арбекова наголошує на тимчасовості нових лексем й умотивовує їхню специфіку тим, що потреба у виникненні цих слів постає «в момент виступу для конкретної ситуації» [1]. К.Ф. Заболотний переконаний, що неологізм $€$ новим словом доти, поки відповідає вимогам спілкування та «сприймається мовцями мови як нове протягом деякого періоду часу» [4]. Натомість Ю.А. Зацний та А.В. Янков наголошують на потребі розширення неологізмів у зв'язку 3 «поліетнічністю, поліваріантністю англійської мови», зауважуючи, що «запозичення 3 одного національного варіанта в інший вважаються у варіанті-рецепторі новими одиницями, навіть якщо вони не є новими для варіанта-донора» [6, с. 6].

Зауважимо, що в мовленні функціонує кілька теоретичних підходів до студіювання неологізмів, зокрема: стилістичний, денотативний, структурний, етимологічний і словниковий.

У межах стилістичного підходу неологізм трактують як слово, новизна якого маркується його новим стилістичним вживанням, прикладом чого 
можуть слугувати слова, що переходять із жаргону або метамови до повсякденної мови (наприклад, термін downtime - вільний час). Відповідно до денотативної теорії неологізми - це слова, що виникають для найменування нових предметів та понять i набувають нових денотативних значень на кшталт smartphone, selfie, e-book. Структурний nidxid визначає неологізми як слова, які мають абсолютно нову мовну й акустичну форму і структуру, наприклад: hobbit Толкієна. За етимологічною теорією неологізм кваліфікують як наявне в мові слово, що розвинулося до нового значення: umbrella 1) річ, яку використовують для захисту від дощу; 2) захисна сила загалом. I, зрештою, науковці, які вивчають неологізми відповідно до лексикографічного підходу, підгрунтя цього напряму вбачають у незафіксованості нового слова в словниках, наприклад, мовна одиниця cinematherapy - «використовувати фільми, як терапію», яка вміщує понад 70000 цитувань у пошуковій системі Google, але поки що не зафіксована в лексикографічних виданнях [4].

Отже, в межах нашої розвідки до нових одиниць зараховуємо лексеми, що виникли в англійській мові протягом останніх двох десятиліть, та, спираючись на зазначені вище підходи, зауважимо, що кожен дослідник має визначити для себе, чи є та чи та мовна одиниця новою для всіх членів суспільства.

Матеріалом дослідження слугували неологізми, вибрані 3 англо-українського словника нової розмовної лексики та фразеології за редакцією Ю.А. Зацного та А.В. Янкова [5] та Oxford Online Dictionary [10].

Мета і завдання статті. У науковій розвідці ставимо за мету в семантичному аспекті виявити найчастотніші групи англійських неологізмів, що вербалізують сферу розмовної лексики XXI ст. Поставлена мета зумовила потребу виконати такі завдання, по-перше, окреслити причини виникнення неологізмів, а по-друге, представити царини, в яких вживають новітні одиниці XXI ст.

Предмет та об'скт дослідження. Об'єктом вивчення $є$ новітня розмовна лексика англійської мови XXI ст., а предметом наукового аналізу семантична структура неологізмів.

Виклад основного матеріалу дослідження. У межах нашого дослідження спробуємо в два етапи, зокрема аналітичний та інтерактивний, репрезентувати неологізми. Аналітичний етап передбачає відбір і лексичний аналіз неологізмів. До аналізу залучили 58\% іменників, 25\% дієслів, 13\% прикметників і 4\% абревіатур, до яких уналежнюємо композиційно складні, розгорнуті словосполучення, дібрані 3 англо-українського словника нової розмовної лексики та фразеології за редакцією Ю.А. Зацного та А.В. Янкова [5] та Oxford Online Dictionary [10].
Важливим $\epsilon$ те, що превалюють однослівні мовні одиниці, які здебільшого виражені іменниками, що свідчить про потребу носіїв мови називати явища або ситуації.

Зважаючи на те, що неологізми активно використовують у мовленні, вважаємо доречним у межах нашого дослідження виокремити 5 основних сфер функціонування нових розмовних одиниць:

- громадське і повсякденне життя: wine o'clockправильний час для вживання вина; cidery - місце, де робиться сидр; fandom - бути фанатом чого- або кого-небудь; sodcasting - вмикати музику через динамік телефону в публічному місці; to mansplain пояснення чоловіком жінці певний речей звисока без знання проблеми; facekini - маска, що одягають влітку (на пляж) на обличчя, аби уникнути опіку; patchwriting - процес, коли автор у тексті використовує власностворені слів;

- комп 'ютерні технології та соиіальні мережі: selfie- фотографія самого себе, автопортрет; to rageуникати якоїсь діяльності, що стала приносити негативні емоціï; $A F K$ - away from the keyboard; second screening - водночас дивитися телевізор та перевіряти смартфон, tablet computer - ноутбук, смартфон; webisode - епізод серіалу, що транслюється в мережі; to pocket-dial - ненавмисно зателефонувати будь-кому через те, що телефон лежить у кишені, crowdsourcing - діяльність із залученням великої групи людей; geobragging - постійно оновлювати свою геолокацію, прагнучи привернути увагу або змусити інших людей заздрити; murder-cam - апарат, що робить 3D-фото місця злочину;

- антропоцентричні номінації, що характеризують людей та їхні потреби, погляди, упередження: moblivious - дивитися на екран смартфону під час ходьби, не помічаючи навколо себе нічого; sapiosexual - людина, що вважає інтелігентних та освічених людей сексуально привабливими; hangry - бути голодним настільки, щоб стати агресивним; on fleek - дуже хороший, привабливий, стильний; normcore - тренд, в якому звичайні та нестильні речі носять як виклик моді; kitchenalgiaностальгія за стилем ведення домашнього господарства 1950-х років, про що свідчить успіх ремісничих магазинів та ретро-роздрібних торговців, таких як Cath Kidston; rawist - прихильник «екстремальної форми» вегетаріанства, яка полягає у споживанні овочів і фруктів тільки в сирому вигляді.

- соитіально-економічний аспект: Eurogeddon фінансовий колапс в Свропі; squeezed middle - шар населення, що страждає від інфляції; crowdsourcing список фрилансерів, що готові працювати над проблемою чи завданням;

- суспільно-політичний напрям: Brexit - процес виходу Британії з Свросоюзу; hacktivism - діяльність, що ведеться задля піару певних політичних кампаній; indyref - peферендум за незалежність Шотландії. 
У наведеній нижче діаграмі представлено у відсотковому плані найчастотніші сфери функціонування неологізмів (див. рис. 1).

Друга частина дослідження охоплює виявлення ступеня актуалізації лінгвістичних одиниць у мовленні носіїв англійської мови та безпосередньо в опитуванні інформантів - носіїв мови, що проживають на території Великобританії. У процесі опитування інформантів запропонували відповісти на кілька запитань, зокрема про значення слова, частотність його використання, синонімічні еквіваленти та ймовірність щодо потенційної фіксації лексеми в словниковому складі мови.

Результати виявилися дещо несподіваними, оскільки група інформантів у віці від 25 до 45 років визначила значення лише $36 \%$ слів. Однак, коли слова були представлені вже в контексті, інформанти змогли зрозуміти значення 90\% наведених слів. Інформанти вікової групи 20-25 років повідомили, що чули 50\% слів. Утім, активно, на думку опитаних, використовують лише 15-20\% нових слів, які відбиралися для аналізу. Це переважно лексичні одиниці зі сфери повсякденного життя, нових технологій і політико-економічного напряму.

Ставлення інформантів до більшості неологізмів досить негативне. Респонденти охарактеризували їх як «дурні», «непотрібні» і такі, що не здатні надовго закріпитися в англійській мові. 3 цією думкою погоджується більшість людей, що брали участь в опитуванні носіїв мови, зокрема, вікова група від 25 до 45 років.

Така думка не $\epsilon$ новою, вкрай негативне ставлення носіїв мови до нових, незвичних слів спостерігаємо давно. Видання The Telegraph стверджує, що нові слова входять до словнико- вого складу мови настільки швидко, що «проходять повз» навіть певного покоління: «...terms have entered the language so quickly that they have bypassed the entire generation» [11].

Принагідно зазначимо, що 3 лінгвістичного погляду негативна реакція носіїв мови на появу нових, почасти незрозумілих слів не відбиває об'єктивної мовної картини, оскільки 90\% від запропонованих для опитування лексем продукують нові значення для невідомих раніше реалій і лише $10 \%$ становлять ті, що виникли як одиниці молодіжного сленгу та ввійшли до сучасної англійської мови деяких соціальних і вікових груп.

Цікавими й необхідними, на наше переконання, є думки А. Меткалфа, який запропонував використовувати низку чинників, що визначають «життєздатність», або, за висловом П. Кука, «успішність» нового слова «Successful new words». Це частота вживання (frequency), «неочевидність» значення (unobtrusiveness), широта поширення і різноманіття ситуацій використання (diversity of users and situations), потенційна здатність слова утворювати інші форми і значення (generation of other forms and meanings), а також тривалість функціонування самого концепту, вираженого цим словом (endurance of the concept to which the word refers) [8].

Крім того, неабиякі труднощі виникають під час перекладу інноваційних лексем. Перекладати неологізми потрібно з урахуванням контексту, в якому вони перебувають, оскільки лише в такий спосіб можна зрозуміти й представити точне значення неологізмів. Крім того, варто проаналізувати лексему та визначити іiї складники. Наприклад, якщо неологізм утворений

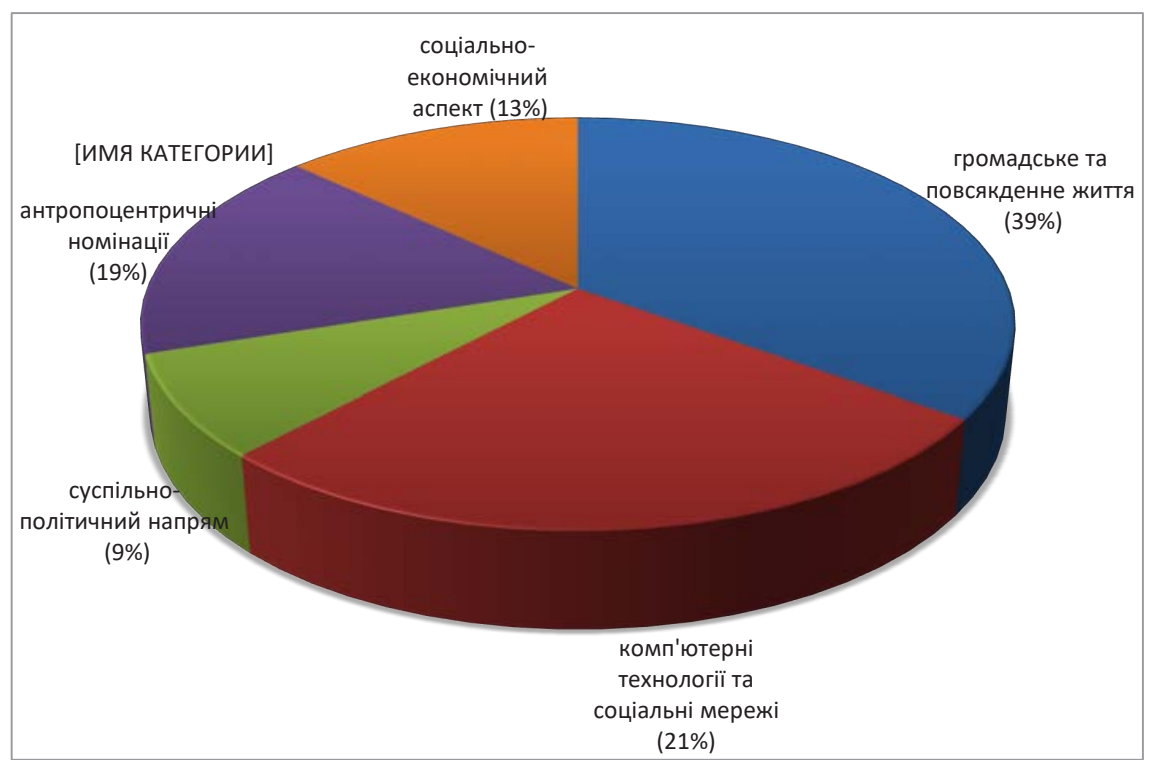

Рис. 1. Основні сфери вживання нових розмовних одиниць 
засобом афіксації, то варто установити афікс та значення тієї лексичної одиниці, до якої афікс доєднано.

Висновки i перспективи подальших розробок. Отже, мовні процеси набувають неабиякої активності, оскільки нині відбуваються динамічні зміни у формуванні мови соціуму. Механізми продукування нових слів мають специфічну природу i їх почасти використовують мовці як стратегії переборювання комунікативних труднощів. Крім того, новотвори вживають для посилення прагматичної спрямованості мовлення, збільшення впливу на адресата та опису нових явищ у суспільстві. Динамічність процесів неологізації лексичного складу сучасної англійської мови створює передумови для подальших наукових пошуків, зокрема, перспективними є дослідження словотворення неологізмів, а також порівняльне вивчення новотворів у різних мовах.

\section{ЛIТЕРАТУРА}

1. Арбекова Т.И. Лексикология английского языка. Учеб. пособие для II-III курсов ин-тов и фак. иностр. яз. Москва : Высшая школа, 1977. $240 \mathrm{c}$.

2. Гурко О.В. Новітні англіцизми в художній літературі. Ученые записки Таврического наиионального университета им. В.И. Вернадского. Серия «Филология. Сочиальные коммуникаиии». 2013. Т. 26 (65). № 1. С. 7-11.

3. Снікєєва С.О. Система словотвору сучасної англійської мови: синергетичний аспект (на мат. новоутворень кінця XX - початку XXI ст.), 2011. $241 \mathrm{c.}$

4. Заболотный К.Ф. Неологизмы в словообразовательной системе английского языка. Черновцы, 1987. 16 с.

5. Зацний Ю.А., Янков А.В. Англо-український словник нової розмовної лексики та фразеології. Вінниця : Нова Книга, 2010. 170 с.

6. Зацний Ю.А., Янков А.В. Інновації у словниковому складі англійської мови початку XXI століття: англо-український словник. Вінниця : Нова Книга, 2008. 360 с.

7. Ткачик О.В. Шляхи поповнення лексичного складу сучасної англійської мови. Наукові записки Національного університету «Острозька академія». Серія: Філологічна. 2015. Вип. 59. С. 211-213.

8. Metcalf A. Predicting New Words: The Secrets of Their Success. Boston: Houghton Mifflin Company, 2004. 312 c.

9. Min-Chang L. A new perspective on the creation of neologisms. Acta Linguistica Asiatica. 2011. Vol. 3 (1). C. 47-59.

10. New Oxford American Dictionary. URL: https:// www.oxfordreference.com/view/10.1093/ acref/9780195392883.001.0001/acref9780195392883
11. The Telegraph. English language is changing faster than ever, research reveals. URL: https:// www.theguardian.com/science/2015/may/01/ icymi-english-language-is-changing-faster-thanever-says-expert

\section{REFERENCES}

1. Arbekova, T.Y. (1977). Leksykolohyia anhlyiskoho yazyka [Lexicology of the English language]. Moscow: High school.

2. Hurko, O.V. (2013). Novitni anhlitsyzmy v khudozhnii literaturi [The latest anglicisms in fiction]. Uchenye zapysky Tavrycheskoho natsyonalnoho unyversytet ym. V. Y. Vernadskoho. Seryia "Fylolohyia. Sotsyalnye kommunykatsyy», vol. 26 (65), № 1, pp. 7-11.

3. Yenikieieva, S.O. (2011). Systema slovotvoru suchasnoi anhliiskoi movy: synerhetychnyi aspekt (na mat. novoutvoren kintsia XX-pochatku XXI st.) [The system of word formation in modern English: synergetic aspects (on the mat. of newly-formed words of late XX-early XXI century)]. Extended abstract of Candidate's thesis. Zaporizhzhia.

4. Zabolotnyi, K.F. (1987). Neolohyzmy $v$ slovoobrazovatelnoi systeme anhlyiskoho yazyka [Neologisms in the word-formation system of the English language]. Extended abstract of Candidate's thesis. Chernivtsi.

5. Zatsnyi, Yu. A., Yankov, A. V. (2010). Anhlo-ukrainskyi slovnyk novoi rozmovnoi leksyky ta frazeolohii [English-Ukrainian dictionary of new colloquial vocabulary and phraseology]. Vinnytsia: New Book.

6. Zatsnyi, Yu.A., Yankov, A.V. (2008). Innovatsii u slovnykovomu skladi anhliiskoi movy pochatku XXI stolittia: anhlo-ukrainskyi slovnyk [Innovations in the vocabulary of the English language at the beginning of the XXI century: EnglishUkrainian dictionary]. Vinnytsia: New Book.

7. Tkachyk, O.V. (2015). Shliakhy popovnennia leksychnoho skladu suchasnoi anhliiskoi movy [Ways to replenish the lexical structure of modern English]. Naukovi zapysky Natsionalnoho universytetu «Ostrozka akademiia». Seriia: Filolohichna, vol. 59, pp. 211-213.

8. Metcalf, A. (2004). Predicting New Words: The Secrets of Their Success. Boston: Houghton Mifflin Company.

9. Min-Chang, L. (2011). A new perspective on the creation of neologisms. Acta Linguistica Asiatica, vol. 3 (1), pp. 47-59.

10. New Oxford American Dictionary. (2015). URL: https://www.oxfordreference.com/ view/10.1093/acref/9780195392883.001.0001/ acref-9780195392883

11. The telegraph. English language is changing faster than ever, research reveals. (2015). Retrieved from https://www.theguardian.com/ science/2015/ may/01/icymi-english-languageis-changing-faster-than-ever-says-expert 